\title{
Chapter 7 \\ Growth Policy and Regional Balance: Developmental State-Building in Myanmar
}

\author{
Toshihiro Kudo and Satoru Kumagai
}

\subsection{Introduction}

Until recently, the Myanmar economy was stagnant and poverty-stricken. The major cause was considered to be the military rule that had started in 1962. The economy, however, had grown even under the military government, slowly though. Such a growth had been facilitated by the development strategy made by the military and quasi-military government before the democratic government started in 2016. How could the belated economic development start under the military rule? Will economic development be sustained under the newborn democracy?

Myanmar seems to provide a window into a late-comer developmental state. Although it is unclear whether it is completely appropriate to call this country a developmental state, it is clear that at least the former leader of the military government, Than Shwe, was influenced by Indonesia's Suharto, Malaysia's Mahathir, and other Asian leaders who headed developmental state-building. Although Than Shwe's open-door strategy in the 1990s failed to boost foreign trade and foreign aid and investment flows, the subsequent leaders' policies have had continuity with his strategy. Since the end of the military rule in 2011, the country has experienced faster economic growth in real GDP per capita than Malaysia, Thailand, Indonesia, and India.

This chapter explores similarities and dissimilarities between the experiences of Myanmar and Southeast Asian emerging-economy states to learn about what kind of political and economic regime delivers economic growth and what drives changes in such regimes. It turns out that the economy of Myanmar has recently been grow-

T. Kudo (凶)

National Graduate Institute for Policy Studies (GRIPS), Tokyo, Japan

e-mail: t-kudo@grips.ac.jp

S. Kumagai

Institute of Developing Economies, Japan External Trade Organization (JETRO), Chiba, Japan

(C) The Author(s) 2019

Y. Takagi et al. (eds.), Developmental State Building, Emerging-Economy State and International Policy Studies, https://doi.org/10.1007/978-981-13-2904-3_7 
ing rapidly because of increasing foreign investments which have brought physical and financial capital, advanced technologies, and managerial resources, increasing foreign aids which have brought infrastructure and human resource development, and rapidly increasing import and export. The economy will grow further as its connectivity with the regional and global economies improves. It seems that openness has played an important role in economic development in almost all East Asian countries. These countries increased economic openness for varying reasons. In general, openness is not necessarily associated with democratization as some countries exhibit high levels of economic openness and low levels of democracy. We argue, however, that in the case of Myanmar, changes toward openness and democracy have been connected with each other probably because one of the major reasons for both changes was the economic sanctions imposed by the major Western countries.

Another purpose of this chapter is to explore a way to cope with regional inequality, which could emerge as a major challenge in the near future due to the country's geographic and ethnic diversity. This country has as many as 135 distinct ethnic groups in the country. ${ }^{1}$ The largest group, Bamar, accounts for about $70 \%$ of the total population, speaks the country's official language, and dominates the government and military. ${ }^{2}$ The second largest group is called Shan people, who account for about 10 of the Myanmar population and live mostly in the Shan State occupying a quarter of the Myanmar territory. Some ethnic groups demanded full autonomy or secession from the Union of Myanmar. The ethnic diversity would keep policy makers sensitive to economic inequality among ethnic groups, which would be closely associated with regional inequality or income gap between center and periphery.

The economic center of Myanmar is Yangon, a port city in the southern part of the country, which was developed by British colonialists as the administrative, military, and commercial center. Although it is no longer the capital city, it remains the largest city of the country today. The capital was relocated in November 2005 from Yangon to a newly developed city, Nay Pyi Taw, about $360 \mathrm{~km}$ north of Yangon and $270 \mathrm{~km}$ south of the second largest city, Mandalay. The relocation was criticized as the military government's economically irrational action. We argue, however, that the relocation may help the country achieve growth with equity to the extent that it contributes to the development of a two-polar economic system with Yangon and Mandalay being economic centers. To explore this possibility, we conduct simulations by using a general-equilibrium, geographic model. The results of simulation analysis indicate that the two-polar system leads to higher growth and less regional inequality than both the unipolar system with Yangon being the single center and the multipolar system with many cities as regional centers.

The rest of this chapter is organized as follows. Section 7.2 describes the features of Myanmar's political and economic regime, its economic geography, and its economic

\footnotetext{
${ }^{1}$ The Myanmar government officially recognized 135 ethnic groups in the country, although their classification is academically controversial. See the website of Ministry of Hotels and Tourism (http://www.myanmar.gov.mm/ministry/hotel/fact/race.htm, accessed July 29, 2018).

${ }^{2}$ The 2014 Myanmar Population and Housing Census (2014 Myanmar Census) was conducted in March-April 2014 after the thirty-one year interval. However, the ethnic population data is not yet released.
} 
policies in more detail. It highlights particularly the geographical distribution of economic activities and trade and investment policies. Section 7.3 reviews some theories on economic growth and regional balance, together with some examples from abroad. Section 7.4 discusses the strategy for future economic development that pays attention to the coordination of regional interests. Section 7.5 concludes the chapter.

\subsection{Development Policies Under Military Rule (1962-2011)}

\subsubsection{Socialist Regime (1962-1988)}

Myanmar shares a long border of 1357 mile with China, 1314 mile with Thailand, 857 mile with India, 152 mile with Bangladesh, and 128 mile with Laos. It also shares coastal waters with Malaysia and Singapore. The eastern borders with China, Laos, and Thailand and the northwestern border with India are mountainous. In the middle part of the country between the mountainous areas, there is a stretch of flatland along the Ayeyarwady (or Irrawaddy) River. The south and north ends of this stretch are Yangon and Mandalay, respectively. They are about $630 \mathrm{~km}$ apart. Mandalay is the former royal capital and the second largest city today with the country's highest density of 1880 people per kilometer. The second highest population density is Yangon's 740 people per kilometer. The new capital city, Nay Pyi Taw, is located halfway between Yangon and Mandalay as shown in Fig. 7.1. This figure also shows the distribution of district-level population density. In contrast to the flatland, the mountainous areas have considerably low densities. In Puta-O, Hpapun, and Bawlake districts, there are less than 10 people per kilometer.

While every part of the country accommodates multiple ethnic groups, minority groups tend to inhabit the mountainous areas near the national borders. Some ethnic groups live across the international borders, and some are armed requesting full autonomy. The military rule began in 1962. The military government adopted a socialist regime seeking the "Burmese Way to Socialism." It restricted foreign trade and investment. The national borders were essentially closed for 25 years. The socialist government nationalized major industries and controlled agriculture. State-owned enterprises led industrialization to some extent, but the impact of industrialization was limited because the vast majority of the population was farmers in rural areas.

\subsubsection{The SLORC/SPDC Era (1988-2011)}

The closed-door policy impoverished the country. In 1988, protests and demonstrations escalated into an anti-government uprising, and the military government responded to it brutally. During the uprising in 1988, the State Law and Order Restora- 
Fig. 7.1 Estimated population density by district (2014, people per square kilometer). Source

Population and Housing Census of Myanmar (2014)

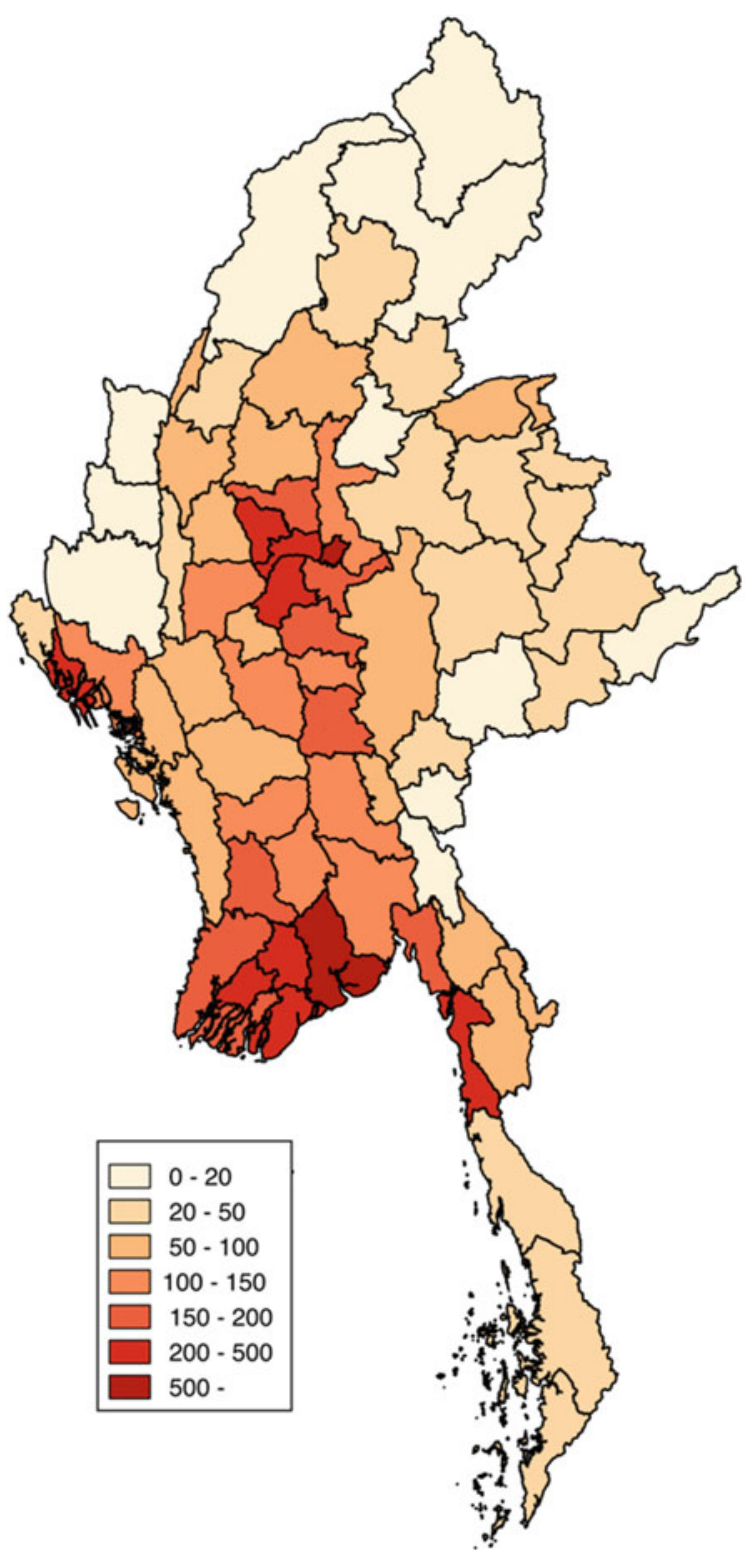

tion Council (SLORC) came into power and declared martial law. It abolished the socialist regime together with the closed-door and self-sufficiency policy. In 1990, Myanmar had a multiparty election. Although the result was a landslide victory of the National League for Democracy (NLD), it was ignored by the military government, which instead cracked down the democratic force and placed democracy icon 
Aung San Suu Kyi under house arrest. These appallingly vicious actions triggered increasingly severe economic sanctions by the Western countries against Myanmar.

From 1992 to 2011, Senior General Than Shwe stayed in power as the head of state and the chairman of SLORC, which was reorganized into the State Peace and Development Council (SPDC) in 1997. Although he was a strong dictator suppressing the free press and abusing human rights, he was also a reformist. He relaxed state control over the economy, privatized state-owned enterprises, legalized cross-border trade with neighboring countries, and started to accept foreign investment. He also promoted the country's participation in the Association of South East Asian Nations (ASEAN).

At least three reasons are conceivable as to why Than Shwe shaped the open door policy and a market-oriented economy. First, it became evident that the closed-door socialist regime would deliver neither economic development nor political stability. Instead it brought poverty, ethnic conflicts, and people's uprising. In other words, learning from failure could be a part of the reason why the military government changed the policy drastically in the early 1990s. Other East Asian countries also learned from failure of adopting the import substitution industrialization strategy before switching to the export-oriented development strategy. Thus, learning from failure seems a common cause for policy change.

Second, Myanmar observed successful economic growth of developmental states of East Asia including South Korea, Taiwan, Singapore and Malaysia. All of them adopted export oriented economic development strategy under authoritarian regime. The Myanmar military must have thought why not they could not do the same thing. It is natural for Myanmar to imitate the same growth strategy as late comer.

Third, while the Western countries imposed economic sanction against Myanmar, Asian countries did not participate in the sanction. ${ }^{3}$ On the contrary, open-door policy adopted by Myanmar was welcomed by neighboring countries, China and Thailand in particular. Following the end of the Cold War, China ceased its dual-track foreign policy toward Myanmar in which it endorsed party-to-party relations between the China Communist Party (CCP) and Burma Communist Party (BCP) in addition to state-to-state relations (Than 2003: 194). Beijing established its good and direct relations with Yangon. Thailand also abandoned its secret strategy of using the Karen and other ethnic insurgents deployed alongside the border areas as a buffer against the Myanmar army and the Burma Communist Party (BCP). Chatichai Choonhavan, the Thai Prime Minister from 1988 to 1991, coined the famous phrase: "Change Indochina from a battlefield to a commercial field." The military government in Myanmar then initiated a ceasefire policy with ethnic insurgents, most of whom occupied the border areas, in 1989. Thus, peace was realized in these areas for the first time since the independence of Myanmar. These political and diplomatic changes paved a way for opening and legalizing Myanmar's border trades wits its neighboring countries.

Myanmar joined the Greater Mekong Sub-region (GMS) of economic cooperation in 1992. This was a significant departure from its traditional isolationist foreign

${ }^{3}$ See Kudo (2009) for details. 
policy. Following this, Myanmar joined the ASEAN and the Bay of Bengal Initiative for Multi-Sectoral Technical and Economic Cooperation (BIMSTEC) in 1997. It joined the Mekong-Ganga Cooperation in 2000 and the Ayeyarwady-Chao PhrayaMekong Economic Cooperation Strategy (ACMECS) in 2003.

Nevertheless, the sanctions imposed by the Western countries must have significantly retarded Myanmar's growth. As mentioned earlier, the economic sanctions started as a result of SLORC's anti-democratic actions. It might have been clear to SLORC/SPDC that if the country had been democratized, the Western countries would not have had a reason for continuing the sanctions. Still SLORC/SPDC was reluctant to democratize the country. Former Prime Minister General Khin Nyunt announced the Roadmap to Discipline-flourishing Democracy of seven step processes in 2003 . However, he was abruptly overthrown from his position and arrested by the military authorities in 2004 .

Than Shwe dreamed "leapfrogging industrialization", but it was never achieved under the international sanctions regime with little FDI and ODA inflow. Moreover, the industrial policy in this era was crude or even irrational. Than Shwe started to establish new state-owned factories and pushed his regional commanders to take initiative in the industrial development of their own regions. As a result, 18 industrial zones in nine Regions and States were established by Myanmar Industrial Development Committee (MIDC). Many of them, however, lacked basic infrastructure, such as sufficient power supply, access to ports, airports, trunk roads, communication facilities, and sewage system. They also lacked skilled labor, large markets, and raw materials. Some of small- and medium-sized factories located in city center were forced by the authorities to move to newly established industrial zones in suburbs where above-mentioned infrastructure and human resources were totally missing.

For example, motorcycle manufacturing was assigned to two industrial zones in Magway Region, a poor region far from both product markets and sources of material supply, because of a regional commander's insistence. All materials were imported from Yunnan Province of China and then transported by land through Mandalay. After motorcycles were "assembled" in Pakokku and/or Yay Nan Chaung Industrial Zones and shipped to Mandalay, the biggest market for motorcycles in Myanmar. Transportation between these industrial zones and Mandalay was redundant and costly, making it impossible for locally made motorcycles to compete with motorcycles smuggled from China. The motorcycle assembly industry might be viable if it had been assigned to the Mandalay Industrial Zone, where skilled workers and machine processing services and parts makers were available. Thus, the crude industrial policy in the Than Shwe era was doomed to failure due to inadequate locational choices and the lack of infrastructure, human resources, and adequate technology.

The relocation of the capital city was implemented also during the Than Shwe era. It was suddenly announced by the government in the middle of 2005 . Even the neighboring countries did not know the plan. For example, Thailand was constructing a new embassy building in Yangon. Before the relocation, Pyinmana, or today's Nay Pyi Taw, was a small town along the road connecting Yangon and the old royal city, Mandalay, with poor infrastructure for communication and transportation. It took eight hours by car from Yangon at that time. Government buildings and 
residential buildings and lifeline facilities for government employees as well as a highway to Yangon were constructed from scratch. The military had already shifted its headquarters to near the new capital, which might be strategically important from the viewpoint of maintaining domestic security as it is a geographic node of the regions. Economically, however, the relocation was criticized as an irrational move. We will return to this point in Sect. 7.4.

\subsection{Development Policies in the Liberalization and Democratization Era (2011-2015)}

\subsubsection{End of Economic Sanctions}

Many reforms in both political and economic arenas started in 2011 under the quasimilitary government led by President Thein Sein, who was a retired general and former prime minister of Than Shwe's military government. His administration started wide-ranging reforms in both economic and political areas. The international community positively responded to his reforms and lifted or relaxed the economic sanctions against Myanmar. As a result, Myanmar's export increased by 1.6 times from 2010 to 2015, and its import increased by 4.1 times for the same period, turning trade balance into red. FDI's inflow also increased drastically from 1.42 billion US\$ in Fiscal Year (FY) 2012 to 9.5 billion US\$ in FY 2015. ODA came back to build both physical infrastructures and legal and institutional infrastructures, too (ADB 2012, p 1).

In March 2016, the NLD that was elected by the people in the general elections of November 2015 established a democratic government. The Union Solidarity and Development Party (USDP) headed by Thein Sein transferred its power to NLD in a peaceful and smooth manner. The newly established government is facing many challenges, and we have not yet know how they promote their reforms.

\subsubsection{Industrial Policy}

Thein Sein's government restructured the industrial policy under the previous regime. For example, the trade liberalization led to increases in motorcycle imports and the termination of the operation of the inefficient motorcycle factories in Magway Region. Recently, a special economic zone (SEZ) began operation on a full scale successfully in Thilawa, only $25 \mathrm{~km}$ away from the downtown of Yangon. In early 2011, the Myanmar government and the Japanese government agreed on the development of this special economic zone by intensively constructing the international standard infrastructure such as electricity, water, road and port, in and around Thilawa SEZ by utilizing Japanese ODA. It has successfully attracted substantial FDI and become 
a leading industrial estate in Myanmar. One successful factor is its proximity to Yangon. Foreign business persons and engineers prefer to live in Yangon. Foreign investors can employ Myanmar management staff and engineers from Yangon. They can utilize Yangon ports and airport for their logistics. Yangon also offers the biggest market in the country. In the future, foreign investors will be able to find and nurture their sub-contractors nearby, since Yangon has the largest industrial cluster in Myanmar.

\subsubsection{Economic Development Strategy}

In June 2012, President Thein Sein declared that his reform strategy had entered into its second phase with focus on economic development (NLM dated 20 June, 2012). ${ }^{4}$ The new strategy consists of four major policies:

(1) sustaining agriculture development toward industrialization and all-round development;

(2) balanced and proportionate development among states and regions in terms of budget and taxation, foreign aid, and foreign and local investment ${ }^{5}$;

(3) inclusive growth for entire population, and

(4) compilation of quality and accurate statistics.

Even after the government was replaced by the NLD government headed by State Counsellor, Aung San Suu Kyi, in March 2016, these policies seem to remain high priority. Prioritizing agriculture was reasonable as agriculture accounted for $36 \%$ of GDP, a majority of labor, and $25-30 \%$ of export earnings. Even in manufacturing production, the food processing industry and other natural-resource-based industries accounted for large shares. It is natural to view agriculture as a source of broadbased development and poverty reduction. Inclusive growth for entire population was a new word for Myanmar, and no one disagreed with the concept. Myanmar's official statistics was obsolete and narrowly covered the country's economic and industrial situations. It was critically important for policy makers to have timely and accurate statistics.

However, these policies are not easy to materialize. In particular, achieving a regional balanced development is a challenge. In reality, this policy objective was inherited to the present government from the earlier regimes. It is considered to be critically important for nationwide peace in a country with ethnic minority insurgencies mostly in mountainous states (not in the proper regions) along the borders with

\footnotetext{
${ }^{4}$ The government submitted a five-year short-term National Plan (FY2011-FY2015) to the parliament. The Myanmar government set a bold target of raising GDP per capita by 1.7 times in five years, which critics considered to be unrealistic.

${ }^{5}$ Myanmar is administratively composed of seven Regions and seven States. Seven Regions are mainly inhabited by Burmese, the major ethnic group, and seven States are mainly inhabited various ethnic minorities such as Shan, Karen, Kachin, Rakhine, Chin, Mon and so forth. Population density of seven Regions are generally higher than that of seven States.
} 
neighboring countries. The pursuit of economic equality, however, could harm economic growth (Brülhart and Sbergami 2009). As Sonobe (2018) argues in Chap. 7 of the first volume of this series, sustainable economic growth is driven by technological and institutional innovations in a broad sense, including borrowing ideas and practices from abroad, and innovations take place in economic agglomerations (i.e., places where economic activities are concentrated) rather than peripheries and inevitably create winners and losers. It is hard to achieve growth with equity without a special strategy or favorable condition. We discuss such a strategy and a condition in the next section.

\subsection{Geography of Industrial Development}

\subsubsection{Estimated Population and GDP by District}

Myanmar has geographical and climatic diversity. At the national level, Myanmar's population density is about 80 people per square kilometer. It is lower than Vietnam (290 people per square kilometer, year 2010) and Thailand (130 people per square kilometer, year 2010). These two countries have population sizes and territory sizes comparable to those of Myanmar. The regional variation in population density, however, is so great in Myanmar that national average does not mean much to the effort to understand the economic geography of this country.

Figure 7.1 shows the distribution of population by district. The central regions along the Ayeyarwady River have generally high population density. Mandalay has the highest density of 1880 people per square kilometer, which is followed by that of Yangon, 740 people per square kilometer. These two areas are the center of population agglomeration. On the other hand, the population of mountainous districts is very low. Some areas, including Puta-O, Hpapun, and Bawlake, have less than 10 people per square kilometer.

The availability of regional GDP data is limited in developing countries. It is possible to estimate the regional distribution of economic activities by using the distribution of nighttime lights because it is well known that the two distributions are closely correlated. Taking the national GDP as given, we estimated the regional distribution of GDP by applying the standard methodology (e.g., Ghosh et al. 2010) to the nighttime light data and land-use data. ${ }^{6}$ The results are shown in Fig. 7.2, which compares the distribution of GDP density (that is, GDP per $\mathrm{km}^{2}$ ) in Myanmar to those in Thailand and Vietnam.

Thailand has a unipolar or mono-centric spatial distribution of economic activities whereas Vietnam is a two-polar country. The single center of Thailand's economic activities is Bangkok. In Vietnam, Hanoi is the center of the northern part of the country and Ho Chi Minh City is the center of the southern part. In Myanmar,

\footnotetext{
${ }^{6}$ See also Keola et al (2015).
} 

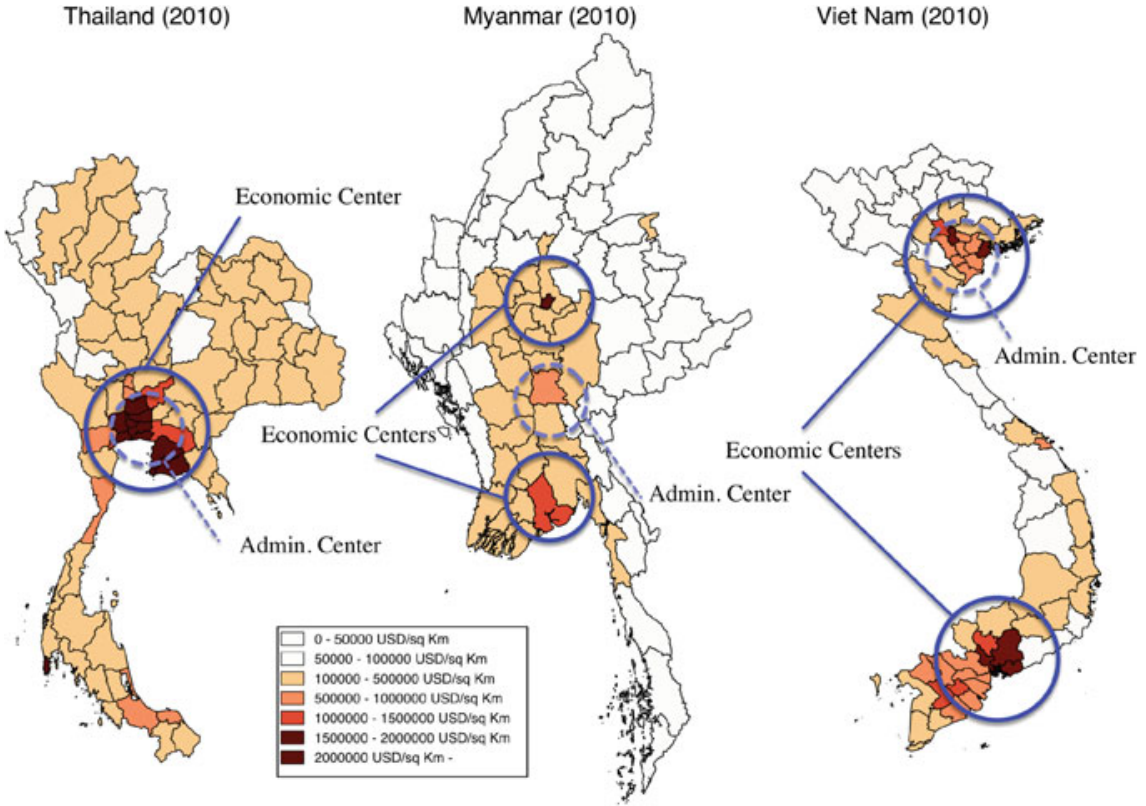

Fig. 7.2 GDP density of Thailand, Myanmar and Vietnam. Source Authors based on IDE-GSM dataset

Table 7.1 The primary-to-secondary-city ratios of population and GDP (2010)

\begin{tabular}{l|l|l|l}
\hline & Primary and secondary cities & Population & GDP \\
\hline Thailand & Bangkok:Chaing Mai & $5.3: 1$ & $25.4: 1$ \\
\hline Myanmar & Yangon:Mandalay & $4.3: 1$ & $4.1: 1$ \\
\hline Viet Nam & Ho Chi Minh:Hanoi & $2.0: 1$ & $3.4: 1$
\end{tabular}

Source Authors calculation based on IDE-GSM dataset

Yangon, Nay Pyi Taw, and Mandalay have high levels of GDP per capita. Table 7.1 illustrates the extent of the primary-city concentration in Thailand in comparison with Vietnam and Myanmar. Bangkok is five times as large as Chaing Mai, the second largest city, in terms of population but it is 25 times as large in terms of GDP. Thus, Bangkok is nearly five times as rich as Chaing Mai in terms of GDP per capita. The income gap between the primary and secondary cities is much smaller in Vietnam and non-existent in Myanmar according to this table.

Table 7.2 shows the spatial Gini coefficients of selected countries. The spatial Gini coefficient takes a value of 1 if all the activities are concentrated in one region and 0 if $n$ regions have an equal share of economic activities. ${ }^{7}$

\footnotetext{
${ }^{7}$ Note that it is not proper to compare the spatial gini coefficients for different countries because it is affected by the definition of region. However, in the simulation by IDE-GSM, one tendency is that coefficients increase for all the countries in 2030 compared with 2005 , while the coefficient
} 
Table 7.2 Spatial Gini coefficients, 2005

\begin{tabular}{l|l}
\hline Country & Spatial Gini \\
\hline Myanmar & 0.280 \\
\hline Thailand & 0.471 \\
\hline Vietnam & 0.402 \\
\hline Cambodia & 0.399 \\
\hline Laos & 0.266 \\
\hline Malaysia & 0.249 \\
\hline Indonesia & 0.507 \\
\hline Philippines & 0.592 \\
\hline China & 0.412 \\
\hline Japan & 0.095 \\
\hline Korea & 0.068 \\
\hline Taiwan & 0.416 \\
\hline India & 0.349 \\
\hline Bangladesh & 0.150
\end{tabular}

Source Authors' calculation based on IDE-GSM simulation results

\subsubsection{Locations of Industries}

Figure 7.3 shows the number of plants by five major industries and by five major industrial areas as of April 1997. ${ }^{8}$ The five major industries are food products, textiles, wood, wood products, metal products, motor vehicles and trailers. They accounted for $88 \%$ of the total private registered industrial enterprises in the country. The five major industrial areas are Yangon, Mandalay, Bago, Ayeyarwady, and Sagaing. They accounted for about $70 \%$ of privately owned plants registered at the Directorate of Industrial Supervision and Inspection (DISI).

From Fig. 7.3, there are several noteworthy findings. First, the food processing industry accounts for $63 \%$ of all enterprises in the country. Even among the five major industries, the food processing industry is by far the most dominant industry in terms of the number of enterprises. Second, however, the situation is different in Yangon and Mandalay. For these economic centers, the food processing industry is not as important as in other regions, and other industries are active. Mandalay and its vicinity account for nearly $80 \%$ of the nation's textile manufacturers, whose main products are in many cases traditional clothing such as "longyi" (sarongs) and cotton blankets.

for East Asia as a region decreases during the same period. This means that economic activities are expected to agglomerate intra-nationally but disperse inter-nationally.

${ }^{8}$ The data source for this figure is the Directorate of Industrial Supervision and Inspection (DISI) of Ministry of Industry (1), now the Ministry of Industry. The data is outdated, but the industrial structure had changed little in the last decade, and the picture presented here is still relevant to around Year 2010. 


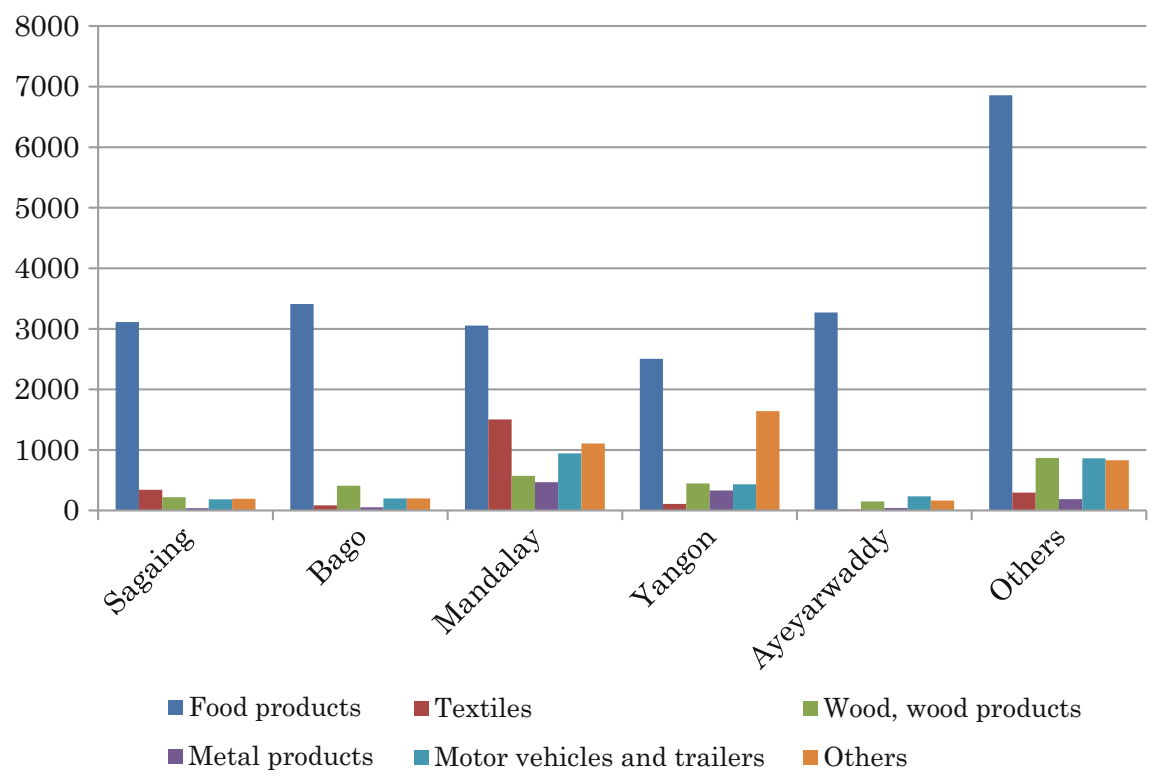

Fig. 7.3 Number of private industries in major regions by business categories, as of April 1997. Source DISI, Ministry of Industry (1)

Third, Mandalay has an industrial zone which is a cluster of automobile-related businesses. The majority of automobiles in the country are second-hand models made more than ten years ago. The demand for repair services and spare parts are naturally high. The Mandalay industrial zone satisfies a large part of these demands and also accommodates a number of plants producing electric appliances, agricultural machines and equipment, and other types of machinery. Fourth, Yangon is a more diversified industrial center and has a number of plants in miscellaneous or "other" industries, which include rubber and plastic products, publishing and printing, chemical products, and paper manufacturing.

In this country, enterprises are predominantly small-scale, even though even largescale enterprises by the standard of Myanmar can be medium- or small-scale by the standard in developed countries. ${ }^{9}$ Small-scale enterprises account for $57 \%$ of employment in the country, $37 \%$ of investment, and $36 \%$ of production output. Large-scale enterprises are more capital-intensive than medium- and small-scale enterprises. They account for $24 \%$ of employment, $40 \%$ of investment, and $37 \%$ of output (Kudo 2012). Of large-scale private plants, $43 \%$ were located in Yangon and $21 \%$ were in

\footnotetext{
${ }^{9}$ In Myanmar, a plant is considered to be large-scale either (1) if the amount of investment is in excess of 5 million Kyat (about 6250 US dollars), (2) if yearly production output exceeds 10 million Kyat (about 12,500 US dollars), (3) power equipment of 50 horsepower or higher, or (4) if the number of employees exceeds 100 .
} 
Mandalay, and 20\% in Sagaing, Bago, and Ayeyarwady combined in 2009. In other areas, there were virtually no large-scale plants.

\subsubsection{Economic Agglomeration and Growth}

Inevitably, economic growth is geographically uneven because some regions have more advantage in doing business than other regions. Workers and firms tend to be attracted to developed regions where they seek higher wages and larger markets. The key word is economic agglomeration, which is either the geographic concentration, as a phenomenon, of economic activities or the place where economic activities agglomerate.

In economic agglomerations, skilled workers are more available, and jobs requiring special skills are more available to workers with such skills than in remote, separated areas; the division of labor among firms is more developed because of large scales of production; and new ideas and useful knowledge are more available because of the scale and diversity of industries, occupations, and expertise. Thus, economic agglomerations tend to have faster economic growth, which would in turn reinforce the advantages of the agglomerations to the extent limited by the negative effect of agglomeration; that is congestion.

Among the enormous literature on economic agglomeration, two studies are particularly noteworthy for the purpose of this chapter. Henderson (2003) examines growth enhancing effects of urban concentration for some 70-80 countries for the period 1960-1990 in 5 year intervals and argues that (1) economic concentration in the country's primary city has pro-growth effects at the beginning, but this effect peaks out once the effect of congestion outweighs the benefits of agglomeration, (2) the extent of urban concentration corresponding to the highest economic growth declines as output per worker increases. Thus, richer economies should have less congested cities. Brülhart and Sbergami (2009) find supportive evidence that the agglomeration of economic activity boosts economic growth until the per capital income of the country reaches about 10,000 US dollars (2006 prices).

These studies suggest that there is a trade-off between economic growth and regional equality in countries with income below a certain threshold level. It is probably not a good idea to emphasize regional equality too strongly when a country is in its early stage of economic development. Fujita and Thiesse (2002, p 391) argue that "even those who stay in the periphery are better off than under dispersion provided that the growth effect triggered by the agglomeration is strong enough." Even residents in the economic periphery benefit from the economic growth of the center as the growth increases the variety of products and services available to them and the demand for migrant labor from the periphery. According to Henderson's (2003) model, a 0.1 standard-deviation increase or decrease (that is, over- or underconcentration) in the share of economic activities in the primary city from the optimal share would reduce the annual per capita GDP growth rate by $0.6 \%$. 
An implication of the literature reviewed above for the economic development of Myanmar is that the concentration of productive activities in Yangon is costly not only from the viewpoint of state building and domestic security but also from the congestion viewpoint. The question of what the appropriate level of concentration in Yangon is may translate into a question of whether Myanmar should have unipolar, two-polar, or multipolar economic geography. To address this question, we use a geographical simulation model.

\subsubsection{Poverty Situation}

Before embarking on, it seems useful to review the poverty situation in the country. Figure 7.4 shows the poverty situation by state or region. The horizontal axis measures the poverty share; that is, the percentage of the national poverty population belonging to the state or region in question. The vertical axis measures the poverty incidence; that is, the percentage of the poor in the population of the state or region in question. The state/region with highest poverty share is Ayeyarwady (18.6\%) followed by Mandalay (15.0\%) and Rakhine (12.2\%). The state/region with highest poverty incidence is Chin $(73.3 \%)$ followed by Shan East $(46.4 \%)$ and Rakhine $(43.5 \%)$.

Different strategies of poverty eradication must be set for states/regions where the poverty incidence is not too high but the poverty share is high (locates lowerright), and for the states/regions the poverty incidence is high while the poverty share is low (locates upper-left). The former case includes Ayeyarwady, Mandalay and Magway, and the latter includes Chin and Shan East. For the former case, industrial development in and around these states to absorb surplus labor force is a possible strategy. For the latter case, re-distribution of income may be a better solution because it is difficult to develop industries in the place where the population is very small or the population density is very low. A specific policy is needed for Rakhine, the state with both high poverty share and high poverty incidence with a complex ethnic situation.

Yangon has a poverty share of $8.1 \%$. If combined with neighboring Ayeyarwady, their poverty share becomes $26.7 \%$. If Yangon takes care of the poverty population in Mandalay and Magway, part of populated and poor Central Dry Zone (CDZ), the share reaches $50.6 \%$, just above half of the national poverty population. This is clearly too much for Yangon alone. A poverty eradication strategy depending on mono-centric economic agglomeration in Yangon has some risk. Considering that Mandalay already has relatively high economic agglomeration, it is more reasonable for Mandalay to take care of its own poverty population as well as the poverty population of neighboring Magway (and Sagaing). For Myanmar, it seems to be desirable to have a two-polar economic structure like Vietnam.

Fortunately, Myanmar is surrounded by more developed economies with high economic growth such as China, Thailand, India, Bangladesh, and Lao PDR. Figure 7.5 shows that some of the eastern border cities of Myanmar have higher levels of income, 


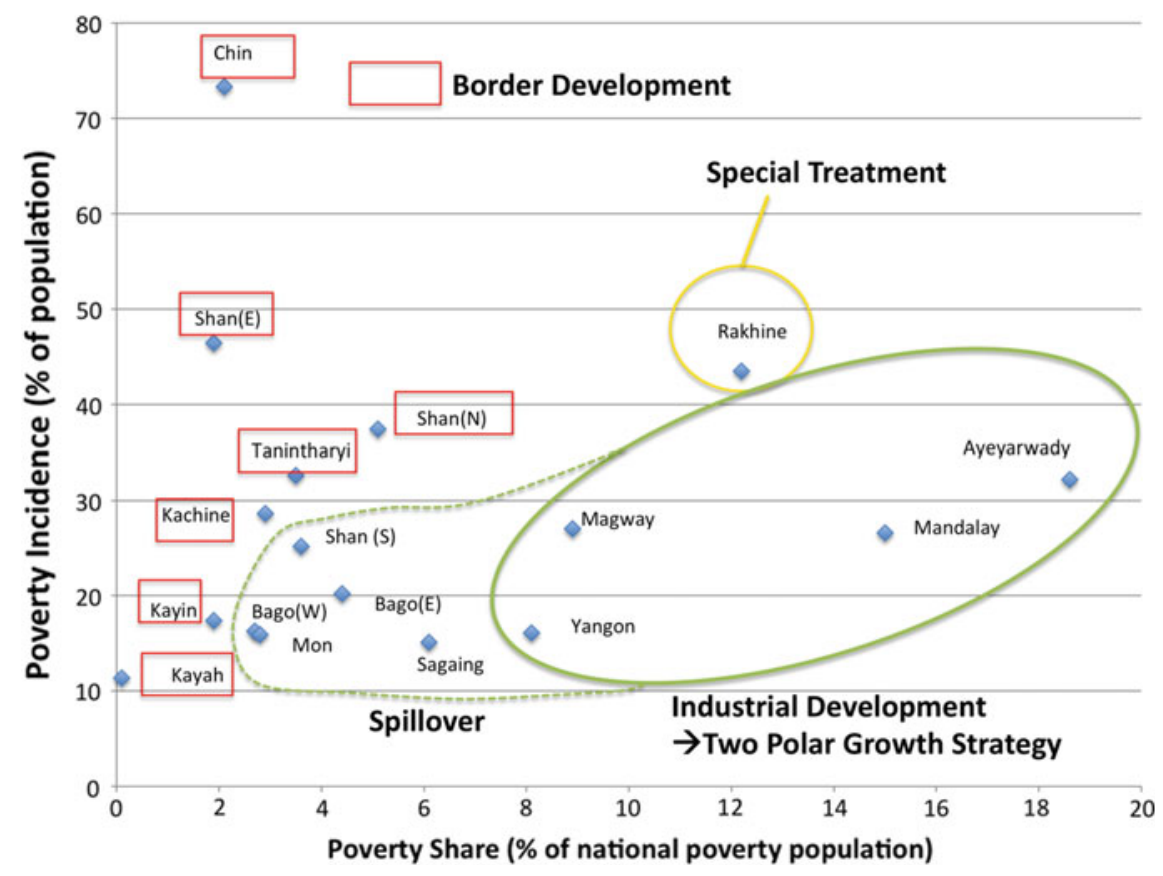

Fig. 7.4 Poverty situation and development strategy by state/region (2010). Source Authors based on UNDP (2011)

and this is probably due to closer links with its emerging neighbors like China and Thailand. Conversely, western border cities have thus far failed to develop through links with their neighbors India and Bangladesh. Given experiences of border cities with China and Thailand, there are ways for western border cities to develop via enhanced connectivity with India and Bangladesh.

\subsubsection{A Simulation Analysis}

The geographical simulation model that we use below is the one developed by the Institute of Developing Economies (IDE-GSM). For details of this simulation model, see Kumagai et al. (2012a, b). We assume that the unipolar development strategy is to double the productivity in Yangon in 2013 exogenously. Similarly, the twopolar development strategy and the multipolar development strategy are respectively assumed to double the productivity in both Yangon and Mandalay and that in 13 regions in 2013 exogenously. The resulting increases in GDP of the country and changes in the geographical distribution of income over time from 2005 to 2030 are compared with those increases and changes under the baseline case, in which productivity grows at a rate projected based on the past data. 


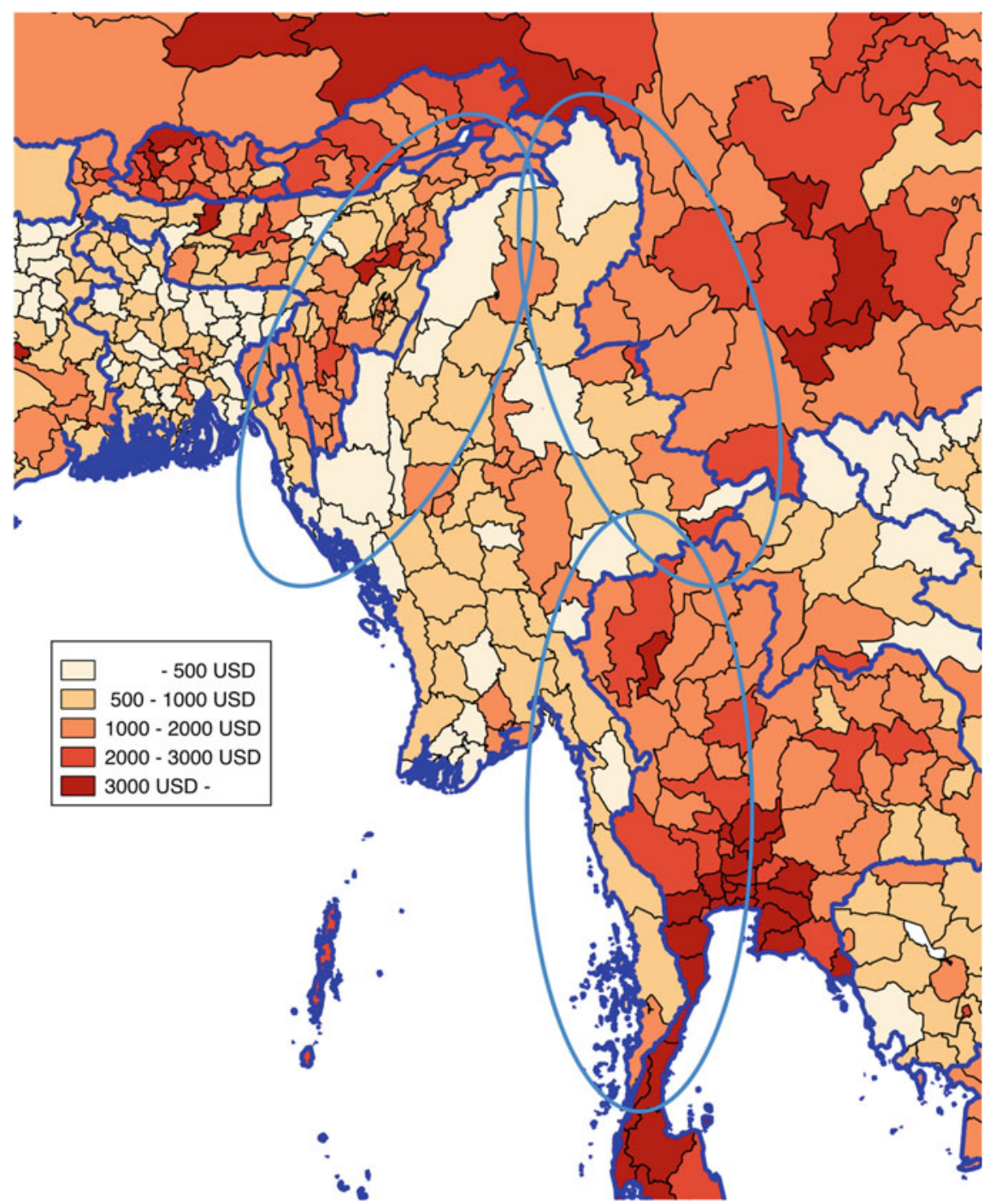

Fig. 7.5 GDP per capita for Myanmar and its neighbors (2010). Source Authors based on IDE-GSM dataset

The results of simulations are summarized in Tables 7.3 and 7.4. In the baseline case, the national GDP will be 3.51 in 2030 where GDP in 2005 is normalized to 1 (Table 7.3); Yangon's share of the national GDP, which is $19 \%$ in 2005, will increase to $26 \%$ in 2030 (Table 7.4); and Mandalay's GDP share, which is 5\% in 2005, will also increase to $11 \%$. Under the unipolar strategy, GDP per capita in 2030 will be 4.93 (Table 7.3); Yangon's GDP share will be 55\% (Table 7.4); Mandalay's share will be $6 \%$. 
Table 7.3 Projected GDP per capita in 2030 by development strategy (National GDP per capita in $2005=1$ )

\begin{tabular}{l|l|l|l|l}
\hline & $(1)$ & $(2)$ & $(3)$ & $(4)$ \\
\cline { 2 - 5 } & National & Seven regions & Seven states & Ratio (2)/(3) \\
\hline Actual GDP per capita in 2005 & 1.00 & 1.03 & 0.92 & 1.12 \\
\hline Projected GDP per capita in 2030 & \multicolumn{5}{|l}{} \\
\hline No strategy (simple projection) & 3.51 & 3.63 & 3.15 & 1.15 \\
\hline Unipolar strategy & 4.93 & 5.47 & 3.14 & 1.74 \\
\hline Two-polar strategy & 5.06 & 5.64 & 3.15 & 1.79 \\
\hline Multipolar strategy & 4.10 & 4.35 & 3.33 & 1.30 \\
\hline Two-polar + connectivity strategy & 5.17 & 5.75 & 3.26 & 1.76 \\
\hline
\end{tabular}

Source Authors' calculation based on IDE-GSM simulation results

Table 7.4 GDP share of Yangon and Mandalay by development strategy

\begin{tabular}{l|l|l}
\hline & GDP share of Yangon & GDP share of Mandalay \\
\hline Actual GDP share in 2005 & 0.19 & 0.05 \\
\hline \multicolumn{2}{l|}{ Projected GDP share in 2030 } & 0.11 \\
\hline No strategy (simple projection) & 0.26 & 0.06 \\
\hline Unipolar strategy & 0.55 & 0.19 \\
\hline Two-polar strategy & 0.43 & 0.13 \\
\hline Multipolar strategy & 0.30 & 0.19 \\
\hline $\begin{array}{l}\text { Two-polar + connectivity } \\
\text { strategy }\end{array}$ & 0.42 & \\
\hline
\end{tabular}

Source Authors' calculation based on IDE-GSM simulation results

In the two-polar and multipolar cases, we assume that the costs of increasing the productivity parameter in a region are proportional to its population. The costs of doubling the productivity of a city with a population of five million are assumed to be five times larger than that of a city with a population of one million. We also assume that available public development expenditure is fixed and that if the number of development poles in increased, the expenditure would be shared by all growth pole regions proportional to their population. The increase in productivity of each region is assumed to be proportional to the development expenditure per capita. Suppose, for example, that there is a budget to double the productivity of the first polar region with a population of four million. If this budget is shared with the second polar region that has a population of one million, then the per capita development expenditure under the two-polar strategy becomes 4 million/( 4 million +1 million $)=0.8$ compared with that under the unipolar strategy, and the resulting increase in productivity would be $80 \%$.

Under this set of assumptions, the two-polar strategy would decrease Yangon's GDP share in 2030 from 55 to $43 \%$ and increase Mandalay's share from 6 to $19 \%$, 
compared with the unipolar case, as shown in Table 7.4. The growth performance is slightly higher under the two-polar strategy than under the unipolar strategy, as shown in Table 7.3, which is consistent with the theoretical prediction based on the consideration of congestion diseconomies. The impact of the two-polar strategy in comparison with the unipolar strategy varies across regions and states. The two-polar strategy is also superior to the multipolar strategy in terms of GDP per capita growth in the country as a whole, which is consistent with both the theoretical prediction based on the agglomeration economy consideration and the intuition that scarce development resources should not be spread over too many regions.

Table 7.3 shows not only the national GDP but also the GDP per capita gap between the seven regions and seven states in Myanmar by development strategy. As mentioned earlier, seven regions are located near to the urban center and they are richer than seven states, although there were no big gap between them as of 2005 . The gap considerably widens with a uni-polar and two-polar, while it a little bit widens with a multipolar strategy. The policy objective of growth with equity and inclusive growth will not be achieved with these strategies, particularly a uni- and two-polar ones

Here, we examine a complementary strategy, that is, improvement of connectivity in the border regions. In the improved connectivity scenario, we combined: (a) the customs facilitation measures at some national borders in 2015 and 2020, (b) upgrading the roads connecting these borders through major cities in Myanmar in 2015 and 2020, and (c) connecting Dawei and Kyaukphyu Ports with India and Europe in 2020. To incorporate (a) into the model, the time and money costs are reduced to the half at the following national borders: Tachileik-Mae Sai, Mongla-Daluo, Tamu-Moreh Kanchanaburi-Dawei, Kawthoung-Ranong, Myawaddy-Mae Sot, and Muse-Ruilli.

For (b), we assume the seven routes are assumed to be upgraded. ${ }^{10}$ All of these routes can be developed as economic corridors in Myanmar. For (c), Dawei and Kyaukphyu ports are assumed to be connected with Kolkata, Chennai, and Rotterdam in 2020, and the so-called transit trade through Myanmar is assumed to become possible for Thailand and China.

As shown in Table 7.3, the simulation predicts that improvement in connectivity will increase GDP per capita of the country. Compared with the two-polar case without improved connectivity, the two-polar plus improved connectivity will raise GDP per capita in the seven regions without reducing GDP per capita in the seven states, thus narrowing the income gap between center and periphery. Table 7.4 shows the GDP share of Yangon is slightly reduced by enhancement of connectivity.

\footnotetext{
${ }^{10}$ The seven routes are (1) Yangon-Mandalay (2015); (2) Muse-Mandalay-Kyaukphyu (2015, then upgrading the route to Sittwe in 2020); (3) Myawaddy-Paan-Yangon (2015, then upgrading the route to Pathein in 2020); (4) Yangon-Mandalay second link on the western side of Bago Yoma (2020), (5) Mandalay-Monywa-Tamu (2020); (6) Mongla-Kyinetone-Tachileik (2020); and (7) YangonMawlamyine-Dawei-Myeik-Kawthoung.
} 


\subsubsection{Possible Industrial Development in Periphery}

Another important component of inclusive development is industrial development in periphery. Because of the limitation of space, we do not discuss industries in the periphery in general, but we focus on border industry, which is defined as industry located in border areas of two or more countries (Kudo and Kuroiwa 2009).

The development of border industries is influenced by two major factors: complementary resource endowment and cross-border infrastructure. In the Greater Mekong Sub-region (GMS), Thailand and China are relatively advanced economies. Vietnam is entering the advanced stage of economic development. Cambodia, Lao PDR and Myanmar (CLM) are still in their rudimentary development stage. Border areas between relatively advanced and less developed economies offer their respective complementary location advantages. CLM economies provide migrant labor, while Thailand offers major inputs (materials, parts, and components), technology, and capital. In border areas, complementary resources which exist side by side across borders are combined to produce cost-competitive products. Of course, some of these resources must be transported across the border to be utilized for production in border towns. Thus, a certain degree of cross-border mobility of productive inputs is required for the birth and growth of a border industry.

The second factor is cross-border infrastructure. In East Asia, service link costs, or the cost of connecting remotely located production blocks, have been reduced substantially. This has made it possible for multinational corporations (MNCs) to aggressively exploit wage differences between developed and less developed economies in East Asia and to develop extensive production and distribution networks in the region. Myanmar, however, has yet to be integrated into such networks in spite of its abundant, reasonably well-educated, and low-waged labor force. Underdeveloped infrastructure, notably in transportation and electricity, hinders the country from participating in production and distribution networks. In labor-intensive export sectors, high transport costs could easily wipe out the labor cost advantage.

Border industries could offer a solution to such problems. The required infrastructure investment to connect its border areas with the existing infrastructure in neighboring countries may be far smaller than that for developing a nationwide infrastructure system. For example, firms in Myanmar-Thai border areas could gain access to the well-developed Laemg Chabang Port via well-connected road networks in Thailand. In border areas, firms would also have better access to utility services such as electricity, water, and telecommunications that are provided by more advanced neighboring countries. Thus, firms located in border areas can enjoy all the benefits of lower service link costs (lower transport and communication costs) and more reliable and cheaper utility services (especially electricity) as well as lower labor costs.

In this way, border industry could grow and complement the two-polar growth strategy. The border areas in Myanmar could have industrial development and become frontiers and conduits that absorb the dynamism of emerging countries in the neighborhood, such as Thailand and China at present and India and Bangladesh. 


\subsection{Concluding Remarks}

The Myanmar armed forces headed by Senior General Than Shwe enjoyed perhaps the longest stretch of military rule for 1988-2011 in the modern world. This authoritarian regime obviously sought socio-economic development of the country. Against the image of being a strong and merciless dictator, Than Shwe was actually the introducer of open-door and market-oriented economy to Myanmar after the quarter-century-long "Burmese Way to Socialism". He knew that many Asian countries had long been under authoritarian regime and still developed their economies rapidly. He apparently aimed to establish a so-called developmental state, following some Asian examples of Indonesia's Suharto, Malaysia's Mahathir and so forth.

However, he failed to realize a meaningful economic growth for another quartercentury under the international sanctions, and was finally replaced by a democratic government headed by Nobel Peace Laurate Aung San Suu Kyi after a five-year transition period of quasi-military government headed by President Thein Sein, Retired General. Than Shwe failed to attract Foreign Direct Investment (FDI) and Official Development Assistance (ODA), which was definitely necessary for the Myanmar economy to join global and regional production and distribution networks, mainly due to international sanctions. All his efforts to establish a developmental state made the military politically survive, but failed to realize economic growth. Myanmar was gradually impoverished, and the military government could not stop the exodus of people to the neighboring countries.

Having faced a prolonged stagnation, Than Shwe reverted to a planning-oriented economic policy in order to achieve so-called "leapfrogging industrialization". He started to construct new state-owned factories. At the same time, Than Shwe pushed his regional commanders, de facto powerful lords, to develop their own regions. Under the military rule, it was imperative for regional commanders to show "development" in their regions to climb up ranks in the military. Then, they established industrial estates all over the country regardless location disadvantages and high transaction costs.

After the quarter-century military rule, President Thein Sein assumed power in March 2011, and inaugurated wide-ranging reforms in both economic and political areas. The international community positively responded to his reforms and lifted and/or relaxed sanctions against the Myanmar economy. FDI started to inflow to Myanmar and ODA was resumed to build physical, legal, and institutional infrastructures. Given its rich endowment of resources including a diligent and literate population of fifty one million and rich investment opportunities in a range of sectors, the prospects for Myanmar's high growth is bright.

Entering a democratic era, regional balance has become not only an economic objective but also a political agenda. It is politically imperative for the Myanmar government to reduce the income gap among regions and states and between urban and rural areas. It is also necessary for the government to reduce the incidence of poverty that varies substantially by regions and states. More importantly, this political agenda was again put at the top priority by the NLD government. 
Nevertheless, how to achieve "high" and "balanced" growth is a challenge when we try to see long-term development in Myanmar. We proposed a two-polar growth strategy with border development, an idea that solves two issues with one approach. This strategy would help Myanmar strike a good balance between high growth and low regional inequality by avoiding the excessive dispersion and concentration of economic activities. The World Bank (2009, p 1) conducted an across-the-board study on spatial aspects of economic development, and the main message of the study was that "Economic growth will be unbalanced, but development still can be inclusive". The same can be applied to Myanmar.

\section{References}

Asian Development Bank (ADB) (2012) Myanmar in transition: opportunities and challenges, Aug 2012. Available at https://www.adb.org/sites/default/files/publication/29942/myanmartransition.pdf. Accessed on 21 Oct 2012

Brülhart M, Sbergami F (2009) Agglomeration and growth: cross-country evidence. J Urban Econ 65:48-63

Population and Housing Census of Myanmar (2014) The 2014 Myanmar population and housing census, The Union Report: Census Report, vol 2

Fujita M, Thiesse JF (2002) Economics of agglomeration: cities, industrial location, and regional growth. Cambridge University Press, Cambridge

Ghosh T, Powell RL, Elvidge CD, Baugh KE, Sutton PC, Sharolyn A (2010) Shedding light on the global distribution of economic activity. Open Geogr J 3:148-161

Henderson V (2003) The urbanization process and economic growth: the so-what question. J Econ Growth 8(1):47-71

Keola S, Andersson M, Hall O (2015) Monitoring economic development from space: using nighttime light and land cover data to measure economic growth. World Dev 66:322-334

Kudo T (2009) Border area development in the GMS: turning the periphery into the centre of growth. ERIA Discussion Paper Series, Jakarta

Kudo T (2012) Explanatory note on data sources 4: Myanmar. In: Kuroiwa I (ed) Economic integration and the location of industries: the case of less developed East Asian countries. Palgrave Macmillan, London

Kudo T, Kuroiwa I (2009) Border industry in Myanmar: plugging into production networks through border industry. In: Kuroiwa (ed) Plugging into production networks: industrialization strategy in less developed Southeast Asian countries. Institute of Southeast Asian Studies, Singapore

Kumagai S, Hayakawa K, Isono I, Keola S, Tsubota K (2012a) Geographical simulation analysis for logistics enhancement in Asia. IDE Discussion Paper No. 369

Kumagai S, Keola S, Kudo T (2012b) Myanmar economy viewed at night. Policy Rev Myanmar Econ (4) IDE-JETRO

New Light of Myanmar (NLM) English newspaper in Myanmar

Sonobe T (2018) Middle-Income trap in emerging states. In T Shiraishi and T Sonobe (eds) Emerging states and economies: their origins, drivers, and challenges ahead. Springer

Than TMM (2003) Myanmar and China: a special relationship? Southeast Asian Aff 2003(1):189-210

UNDP (2011) Integrated household living conditions survey in Myanmar (2009-2010): poverty profile. UNDP, Yangon

World Bank (2009) Reshaping economic geography. World Development Report. World Bank, Washington 
Open Access This chapter is licensed under the terms of the Creative Commons AttributionNonCommercial-NoDerivatives 4.0 International License (http://creativecommons.org/licenses/bync-nd/4.0/), which permits any noncommercial use, sharing, distribution and reproduction in any medium or format, as long as you give appropriate credit to the original author(s) and the source, provide a link to the Creative Commons license and indicate if you modified the licensed material. You do not have permission under this license to share adapted material derived from this chapter or parts of it.

The images or other third party material in this chapter are included in the chapter's Creative Commons license, unless indicated otherwise in a credit line to the material. If material is not included in the chapter's Creative Commons license and your intended use is not permitted by statutory regulation or exceeds the permitted use, you will need to obtain permission directly from the copyright holder.

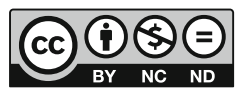

